\title{
Comparative Analysis of Biological Effects Induced on Different Cell Types by Magnetic Fields with Magnetic Flux Densities in the Range of 1-60 mT and Frequencies up to $50 \mathrm{~Hz}$
}

\author{
Cristian Vergallo ${ }^{1}$ (1) and Luciana Dini ${ }^{1,2, *}$ \\ 1 Department of Biological and Environmental Science and Technology (Di.S.Te.B.A.), University of Salento, \\ Prov.le Lecce-Monteroni Snc, 73100 Lecce, Italy; cristian.vergallo@unisalento.it \\ 2 CNR Nanotec, 73100 Lecce, Italy \\ * Correspondence: luciana.dini@unisalento.it; Tel.: +39-083-229-8614; Fax: +39-083-229-8937
}

Received: 25 May 2018; Accepted: 4 August 2018; Published: 6 August 2018

\begin{abstract}
Moderate static magnetic fields (SMFs) are generated from sources such as new-generation electric trams and trains, electric arc welding, and magnetic resonance imaging (MRI) devices, as well as during the industrial production of aluminium, while extremely low frequency pulsed magnetic fields (ELF-PMFs) are produced by house power installations, household appliances, and high voltages transmission lines. Moderate SMFs and ELF-PMFs with magnetic flux densities $(B)$ in the range of 1-60 $\mathrm{mT}$ and frequencies $(f)$ up to $50 \mathrm{~Hz}$ are common MF exposure sources for the population. Even though humans are continually exposed to these MFs, to date no definitive endpoint has been drawn about their safety. In this review, the state of knowledge about the biological effects induced by these MFs on different cell types will be addressed. In our own observation, the putative modulation of $\mathrm{Ca}^{2+} / \mathrm{H}^{+}$and $\mathrm{Na}^{+} / \mathrm{H}^{+}$plasma membrane antiporters of human peripheral blood lymphocytes (PBLs) was found to occur after a $24 \mathrm{~h}$ exposure to a $6 \mathrm{mT} \mathrm{SMF}$, and the bystander effect observed on U937 cells cultivated for up to $6 \mathrm{~h}$ in the conditioned medium harvested from human PBLs previously exposed for $24 \mathrm{~h}$ to the same MF (secondary necrosis induction) will be also herein discussed.
\end{abstract}

Keywords: magnetic field (MF) exposure; moderate static magnetic fields (SMFs); extremely low frequency pulsed magnetic fields (ELF-PMFs); biological effects

\section{Introduction}

The Russian biologist Vladimir Ivanovich Vernadsky mentioned in 1926 that the evolution process of life occurs on a continuous background of magnetic fields (MF), also known as the geomagnetic field [1]. Nonetheless, electromagnetic radiation from electrical appliances, power transmission lines, or radio communication antennas has, in the last half century, aroused public concern, discussion, and protests, because it is considered an electromagnetic pollution. This has pushed the scientific community to carry out studies about the putative detrimental effects of MF exposure on the health of living beings, including humans. Studies performed throughout the last 30 years, rather than yielding clear answers, have provided a series of conflicting outcomes. The conflict of findings found in the literature is mainly due to the wide range of experimental parameters that can be set to perform each investigation. These parameters are:

- source, i.e., an electrically charged object or permanent magnet. If permanent magnets are considered, material composition, size, polar configuration, and support device features are crucial [2]; 
- type of MF, i.e., static or time-varying; therefore, also the magnetic flux density $(B)$ and oscillation frequency $(f)$ must be taken into account [3-7];

- type of biological target, from molecules to a whole organism, by including constitutive differences between in vitro and in vivo model systems. For instance, the MF induced inside the human body depends on the anatomy of the exposed person, e.g., height, posture, body mass index (BMI). The dielectric properties of tissues that change with water content and age are also important [8];

- extent of the exposed area; therefore, also homogeneity and inhomogeneity of the exposure needs to be calculated [2]. It is worth noting that the distribution of the MF induced inside the human body at high frequencies $(f)$ is highly non-uniform; therefore compliance with both local and whole-body energy absorption needs to be demonstrated [8];

- distance of MF source from biological target $[9,10]$. The maximum possible exposure near a specific source often differs by some orders of magnitude from the average individual exposure of a person. For example, at $5 \mathrm{~cm}$ from a vacuum cleaner, $B$ is of about $40 \mu \mathrm{T}$, but at $1 \mathrm{~m}$ it will be around $0.2 \mu \mathrm{T}[9,10]$;

- alternation and duration of exposure [5-7,11-13].

In recent years, the increased exposure of people to different types of MFs, most of which are extremely low-frequency pulsed magnetic fields (ELF-PMFs) or moderate static magnetic fields (SMFs) with $B$ in the range of 1-60 $\mathrm{mT}$ (see Section 3.1) and $f$ up to $50 \mathrm{~Hz}$ (frequency of power supplies in European and most Asian countries is $50 \mathrm{~Hz}$, while American countries use $60 \mathrm{~Hz}$ power supplies), has attracted paramount interest by the scientific community. Thus, a literature review about the biological effects induced on different cell types by these MFs will be herein addressed.

\section{Classification of MFs}

The characteristics that are important in the description of the MF are the oscillation frequency value $(f)$ and the value of its magnitude, i.e., the magnetic flux density, also known as magnetic induction $(B)$. MFs are classified into SMFs, which do not change in intensity or direction over time $(f=0 \mathrm{~Hz})$, and PMFs, which are time-varying $(f>0 \mathrm{~Hz})$, and thus, also named alternating MFs. On the basis of the magnitude of the MF, SMFs generated by a permanent magnet, or by a direct current (DC) which presents a unidirectional flow of electric charge, are classified in:

- weak: $B<1 \mathrm{mT}$;

- moderate: $1 \mathrm{mT} \leq B<1 \mathrm{~T}$;

- $\quad$ strong: $1 \leq B \leq 5 \mathrm{~T}$;

- $\quad$ and ultra-strong: $B>5 \mathrm{~T}$.

According to their $f$ value, PMFs generated by an alternating current (AC), which periodically reverses direction, are classified in:

- $\quad$ extremely low frequency (ELF) PMFs: $f \leq 300 \mathrm{~Hz}$;

- intermediate frequency (IF) PMFs: $300 \mathrm{~Hz}<f \leq 10 \mathrm{MHz}$;

- radio frequency (RF) PMFs: $10 \mathrm{MHz}<f \leq 300 \mathrm{GHz}$.

\section{Moderate SMFs and ELF-PMFs}

\subsection{Exposure Sources}

Man-made moderate SMFs are generated, as explained above, wherever DC currents are used. This happens in some new-generation transportation systems (e.g., electric trains and in developmental magnetic levitation, MagLev, systems), industrial processes (e.g., aluminium production and gas welding), and diagnostic devices (e.g., magnetic resonance imaging, MRI). The general population experiences magnetic flux densities of up to $2 \mathrm{mT}$ inside electric trains and MagLev systems [9]. Workers using electric arc welding are exposed to SMFs of around $5 \mathrm{mT}$ at $1 \mathrm{~cm}$ from the welding 
cables, whereas workers employed in industries processing alumina by electrolytic reduction are exposed to stronger fields, i.e., up to around $60 \mathrm{mT}$ [9]. It has been estimated that approximately 60 million MRI scans are performed worldwide per year [14]. The SMF of MRI scanners in routine clinical systems is generated by permanent magnets, by the flow of a DC through superconductors, and by combinations thereof, working in the range of $0.2-3 \mathrm{~T}$. MRI operators can be occupationally exposed to fields of about $0.5 \mathrm{mT}$ in the vicinity of the console, and occasionally even higher levels while standing by the patient [9]. All these examples show how the exposure of humans to these kinds of MF can occur accidentally or occupationally.

Humans are exposed to different sources of ELF-PMFs in various situations of everyday life. Residential exposure sources are household appliances, power and high voltage transmission lines, domestic installations, and trains; electric power installations, welding, induction heaters, and electrified transport systems are examples of occupational exposure sources. The most prominent frequencies are 50 and $60 \mathrm{~Hz}$ and their harmonics, often called power frequencies [10]. Due to the fact that modern electrical equipment uses electronics instead of transformers for power regulation (e.g., switched power supplies to laptops, drilling tools, chargers of mobile phones, and similar devices), the frequency content of the daily MF exposure has mostly changed by adding odd harmonics. Thus, the third harmonic $(150 \mathrm{~Hz})$ has become another dominant frequency that contributes to the electromagnetic pollution [8]. Only a small percentage of the European population is exposed to levels above a median $B$ of $0.2 \mu \mathrm{T}$ in their homes. Regarding $50 \mathrm{~Hz}$ ELF-PMFs, the International Commission on Non-Ionizing Radiation Protection (ICNIRP)'s reference level for $B$ value is $100 \mu \mathrm{T}$. This maximum threshold value can be found mostly near several domestic appliances incorporating motors, transformers, and heaters [10]. Other ELF-PMFs sources operate in our environment; high voltage transmission lines $(110-400 \mathrm{kV})$ operate at 50 or $60 \mathrm{~Hz}$. Even though the $B$ value depends on the actual current of the line, ELF-PMFs of up to $40 \mu \mathrm{T}$ are possible. Such exposure levels occur only directly below the lines, because magnitude values decrease with the square of distance to the lines. Under intermediate voltage transmission lines $(10-30 \mathrm{kV})$ and distribution lines $(400 \mathrm{~V})$, the exposure levels are much lower $(0.5-3 \mu \mathrm{T})$ [10]. The ELF-PMF generated by an underground current carrying cable is higher than that of a cable belonging to an overhead transmission power line. The reason is that underground power wires are installed at a shorter distance than overhead wires; therefore, the region with a high field is much narrower in the first case. Unfortunately, underground cables are often buried under sidewalks, so people may walk along the region where the field from the cables is highest. Fortunately, when low or moderate power is transmitted through an underground cable, a single cable is used, with the three phases packed very closely together. Thus, the MF reaches negligible values at surface level [15].

\subsection{Cellular Effects of Exposure to SMFs and ELF-PMFs with B in the Range of 1-60 $\mathrm{mT}$ and $f$ up to $50 \mathrm{~Hz}$}

An extensive literature search about the effects of MF exposure on different cell types was performed by means of three bibliographic databases, i.e., Scopus, Web of Science Core Collection and PubMed. For each bibliographic database search, the specific one-block-structured query string "(((extremely low frequency pulsed) OR (moderate static)) AND (magnetic field effect))" was entered into the internal database search-command-line. The following general settings were adopted:

(i) English language;

(ii) timespan from 1988 to 2018;

(iii) document types: articles, reviews, books, chapters, and proceedings.

The selection has been made manually by topic (title, abstract and keywords), without taking into account the impact of the chosen papers (number of citation or IF/SJR of the Journal). Among the findings of the last 30 years (7191 papers with duplicates), only appropriate papers involving SMFs and ELF-PMFs with $B$ in the range of $1-60 \mathrm{mT}$ and $f$ up to $50 \mathrm{~Hz}$ are discussed herein. In cases where 
two or more papers discuss the same topic, the most recent, or the one containing more data, was taken into account.

\subsubsection{Alteration of Electrical Parameters}

Available outcomes highlight how MFs induce contrasting responses, based on electrical parameters, in cell membranes, such as the transmembrane potential, the transmembrane current, and the membrane conductance. For example, a $50 \mathrm{~Hz}, 1-50 \mathrm{mT}$, ELF-PMF induces non-linear changes in both cell membrane conductivity and permittivity in in vitro-cultivated primary embryonic chicken myoblasts after $1 \mathrm{~h}$ of exposure; conversely, when the same cells are exposed for $1 \mathrm{~h}$ to a DC-induced SMF of 1, 3, or $5 \mathrm{mT}$, i.e., values comparable with those of the ELF-PMF used in the same study, no change in the same membrane electrical parameters was observed in comparison to control values $[3,4]$. MF exposure also induces variations in the inner mitochondrial transmembrane potential of differentiated U937 (6 mT, for up to $72 \mathrm{~h}$ ) and SH-SY5Y cells (1.4 mT, $50 \mathrm{~Hz}$, ELF-PMF, for up to $4 \mathrm{~h})[16,17]$. Interestingly, these experimental observations have been mathematically rationalized by Ye et al., (2010). They have provided a theoretical model explaining how a MF (PMF) leads to an induced voltage on the cytoplasmic membrane, as well as on membranes of the internal organelles such as mitochondria, and how these transmembrane potential changes could have a significant impact on their functionality [18] (see Section 3.2.4).

\section{Alteration of Fluidity}

Santoro et al., (1997) analysed the membrane fluidity of Raji cells by steady-state 1,6-diphenyl-1,3,5-hexatriene fluorescence polarization. Polarization values for $72 \mathrm{~h}$ ELF-PMF exposed cells $(2 \mathrm{mT}, 50 \mathrm{~Hz})$ were higher than controls. This indicates that the membranes of MF-exposed cells are significantly less fluid than sham exposed ones [19]. The effect of ELF-PMF on the fluidity of the cell membranes depends on the $B$ value and cell type. Liu (2002) have found that the brain and liver cell membrane fluidity decreased after 2 weeks of exposure to $6 \mathrm{mT}, 50 \mathrm{~Hz}$, ELF-PMFs from the control levels of $1.396 \pm 0.040$ and $2.899 \pm 0.552$ to $1.159 \pm 0.179$ (around $17 \%$ less) and $1.516 \pm 0.204$ (around $48 \%$ less), respectively [20].

\section{Alteration of Building Molecules}

The main molecular constituents of the cell membrane are proteins (extrinsic or intrinsic) and lipids (cholesterol and phospholipids, which are the major component). In the prevailing view of cellular membrane structures, the lipids that make up a bilayer act as solvent for intrinsic proteins that remain embedded in them. Membrane proteins and lipids have directionally dependent physical properties, i.e., are anisotropic molecules. The two most common protein secondary structures are $\alpha$-helix and $\beta$-pleated sheet. Due to the axial alignment of peptide bonds, the $\alpha$-helix has large anisotropy. The regular arrangements of the peptide bonds in $\beta$-pleated sheets also produce substantial anisotropy, but less than the $\alpha$-helix [21].

Membrane proteins and lipids are oriented by a MF, a phenomenon known as diamagnetic anisotropy. It has been demonstrated that a moderate intensity SMF induces the rotational displacement of the membrane phospholipids by virtue of their collective diamagnetic properties. This molecular rotation within the membrane matrix influences the imbedded ion channels, most likely by producing some degree of deformity of their intramembranous segment, i.e., the part of the structure which is responsible for activation [22,23]. ELF-PMF exposure also influences the lipid components of the cellular membrane, and the $\mathrm{N}-\mathrm{H}$ in-plane bending and $\mathrm{C}-\mathrm{N}$ stretching vibrations of peptide linkages, modifying the secondary structures of $\alpha$-helix and $\beta$-sheet contents and producing unfolding process in cell membrane proteins of Hela (41.7-43.6 mT, $50 \mathrm{~Hz}$, ELF-PMF, for up to $1 \mathrm{~min}$ ) and differentiated SH-SY5Y cells (0.81-1.41, $50 \mathrm{~Hz}$, ELF-PMF, for up to $4 \mathrm{~h}$ ) [17,24]. Thus, MF affects membrane proteins either directly, or indirectly through the neighbouring phospholipids $[17,22,23]$. 


\subsubsection{Incidence on Intracellular Calcium Concentration}

Liburdy found that the murine thymic lymphocytes respond to $1 \mathrm{~h}$ of exposure to a $50 \mathrm{~Hz}, 22 \mathrm{mT}$, ELF-PMF through two phases: an early phase, representing the calcium release from intracellular stores, and a subsequent plateau phase, comprising the influx of extracellular calcium across the ion channels [25]. A $50 \mathrm{~Hz}$ ELF-PMF with lower values of both $B$ value and exposure time, i.e., $0.8 \mathrm{mT}$ and $8 \mathrm{~min}$ respectively, induces the uptake of intracellular calcium on murine osteoblasts [26]. Also a SMF is able to alter the intracellular calcium concentration (indicated as $\left.\left[\mathrm{Ca}^{2}\right)\right]_{\mathrm{i}}$ ). Dini et al. have demonstrated that a moderate SMF (6 mT) upregulates $\left.\left[\mathrm{Ca}^{2}\right)\right]_{\mathrm{i}}$ in different cell types (human peripheral blood lymphocytes (PBLs), murine thymocytes, 3DO, U937, HeLa, HepG2, FRTL-5 cells). In particular: (i) SMF affects the release of calcium from the endoplasmic reticulum, as well as its cellular influx, by calcium channels present in the plasma membrane that, in turn, influence the apoptosis onset by triggering (sometimes) or counteracting it (very often) $[2,11,12,16,27]$; (ii) the SMF modulation of $\left.\left[\mathrm{Ca}^{2}\right)\right]_{\mathrm{i}}$ depends on cellular aging. For instance, with respect to control values and after $24 \mathrm{~h}$ of $6 \mathrm{mT}$ SMF exposure, $\left.\left[\mathrm{Ca}^{2}\right)\right]_{\mathrm{i}}$ increased by $30 \%$ in freshly-isolated PBLs, whereas it doubled in 5 day-old samples [27].

In a recent experiment (data published here for the first time), we found that the $\mathrm{pH}$ value of RPMI-1640 culture medium, in which PBLs were cultured for $24 \mathrm{~h}$, increased by 0.2 . Without cells but under exposure condition ( $6 \mathrm{mT} \mathrm{SMF}$ ), the $\mathrm{pH}$ value increases by 0.1 (Figure 1 ). This outcome agrees with the finding of Li et al., who found that the $\mathrm{pH}$ of RPMI-1640 culture medium increased by 0.14 after $8 \mathrm{~h}$ of exposure to a SMF of 85-92 mT [28]. Interestingly, as shown in Figure 1, the $\mathrm{pH}$ of RPMI-1640 culture medium harvested from a culture of PBLs exposed to a SMF of $6 \mathrm{mT}$ for $24 \mathrm{~h}$ decreased either with respect to the non-exposure condition ( 0.4 less) or to the culture medium which was only SMF-exposed (0.1 units less). In 1978, Bevza and Kucherenko first discovered the $\mathrm{Ca}^{2+} / \mathrm{H}^{+}$ antiporter in the plasma membrane of murine PBLs. The same authors found that at least one of the transporting cations' concentration gradients through the outer plasma membrane is the moving force that allows such an exchange to occur [29]. Therefore, as with the present here, it could happen that the same MF influences the plasma membrane calcium channels by operating the plasma membrane $\mathrm{Ca}^{2+} / \mathrm{H}^{+}$antiporter, in turn leading to the extrusion of $\mathrm{H}^{+}$ions outside of the cell, and thus decreasing the $\mathrm{pH}$ value of the RPMI-1640 culture medium. However, the same $\mathrm{H}^{+}$extrusion observed under $6 \mathrm{mT}$ SMF exposure conditions could occur following the induction of the plasma membrane $\mathrm{Na}^{+} / \mathrm{H}^{+}$ antiporter, which is also involved in the regulation of intracellular $\mathrm{pH}$ [30].

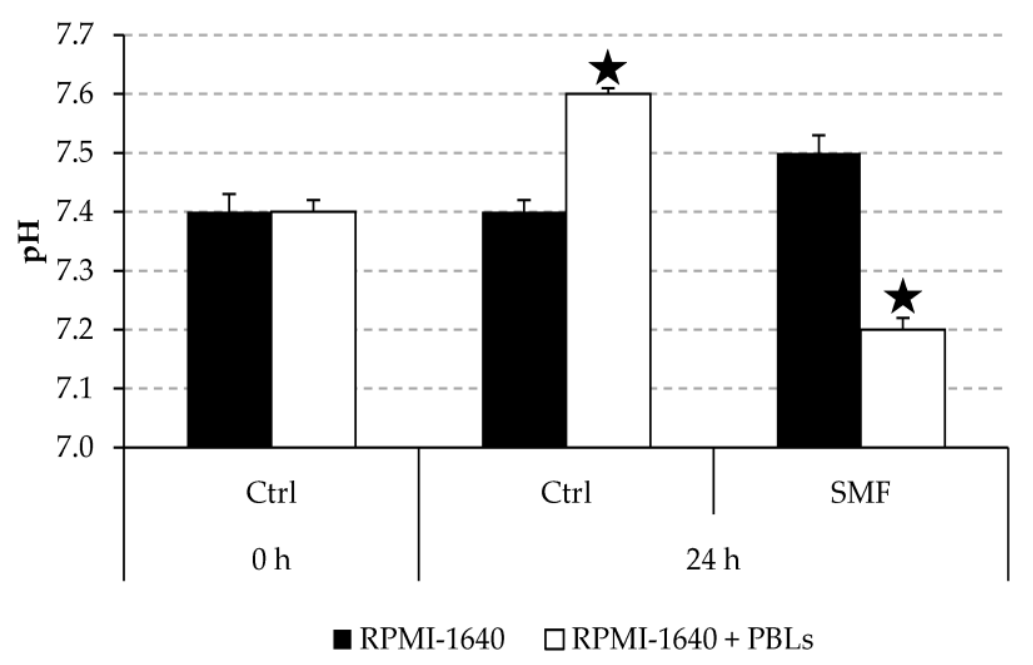

Figure 1. Effect of a $6 \mathrm{mT}$ SMF on the $\mathrm{pH}$ value of RPMI-1640 culture medium (with $10 \%$ fetal bovine serum, FBS) for up to $24 \mathrm{~h}$, with or without PBLs. A star indicates a significant value with respect to all other values $(p \leq 0.01)$. 


\subsubsection{Incidence on Cell Shape, Cytoskeleton, Cell Adhesion and Differentiation}

MF exposure can modify the shape of different cell types. These shape changes, which involve the whole cell or specialized components of it, depend on the kind of MF, on the cell type considered, as well as on their corresponding mode of growth $[7,11,12,16,19,27,31,32]$. For example, PBLs lose their round shape and became irregularly elongated [11], whereas the surface microvilli of U937 cells, which are commonly few and short, become abundant and lamellar-shaped under exposure conditions, i.e., after $24 \mathrm{~h}$ exposure to a SMF of $6 \mathrm{mT}[11,16,32]$. Similarly, Raji cells exposed for up to $72 \mathrm{~h}$ to a $2 \mathrm{mT}$, $50 \mathrm{~Hz}$, ELF-PMF show a more elliptical shape but exhibit morphological alterations in the plasma membrane, such as a complete loss of microvilli [19]. Control HaCaT cells have typical polygonal epithelial morphology, while $96 \mathrm{~h}$ exposed cells $(2 \mathrm{mT}, 50 \mathrm{~Hz}$, ELF-EMF) appear in totally confluent monolayers [31]. A $24 \mathrm{~h}$ exposure to a $10 \mathrm{~Hz}, 5 \mathrm{mT}$, ELF-PMF induces significant morphological changes in U87 cells, mainly including processes and soma alteration, decreased body mass, and increased cell surface, shortening of the processes, shrinkage/swelling of the soma, and apoptotic-like cell morphologies (surface blebs, pyknotic nucleus) [7]. Microvilli are mainly composed of cytoskeletal components. Therefore, the alterations induced by the MF exposure are the result of alterations affecting the cytoskeletal components (actin filaments, microtubules and intermediate filaments) which help the cells to maintain their shape and internal structures. In fact, a de-arrangement of the F-actin microfilaments, with their depolymerisation and marginalization from the centre towards the cell membrane, was found in differentiated U937, as well as in Raji or HaCaT cells exposed to a $6 \mathrm{mT}$ SMF (for up to $72 \mathrm{~h}$ ) or to a $2 \mathrm{mT}, 50 \mathrm{~Hz}$, ELF-EMF (for up to 72 or $96 \mathrm{~h}$ ), respectively [16,19,31].

Dini et al., (2005 and 2009) found that some substances (i.e., 12-0-tetradecanoyl-13-phorbol acetate (TPA), low concentration of glutamine, dimethyl sulfoxide) induce U937 cell differentiation through a progressively lower degree. Differentiated U937 cells shift from a round to a macrophage-like morphology, from suspension to adhesion growth, and acquire phagocytotic activity, with the cytoskeleton adapting accordingly. Exposure to a SMF of $6 \mathrm{mT}$ for up to $72 \mathrm{~h}$ decreases the degree of differentiation induced by the same differentiating molecules, with a consequent fall in cell adhesion and increased polarization of pseudopodia and cytoplasmic protrusions. As a result of the decrease in differentiation, a delay in engulfing dying cells was also observed [16,32]. Interestingly, when Manni et al., (2002) investigated the effects on HaCaT cells of exposure for $96 \mathrm{~h}$ to an ELF-EMF of $2 \mathrm{mT}$ and $50 \mathrm{~Hz}$, they found that both the percentage of adherent cells and the progression of cell differentiation status increased. Nevertheless, a higher percentage of the exposed cells showed a modified pattern of adhesion and differentiation markers, and did not reach the final state of differentiation [31]. Ayşe et al., (2010) found that the effects of MF on differentiation also depend on the specific exposure modality. They investigated the effect of a $5 \mathrm{mT}, 50 \mathrm{~Hz}$, ELF-EMF on the differentiation of K562 cells on two different time scales, i.e., a single $1 \mathrm{~h}$ exposure or a daily exposure of $1 \mathrm{~h}$ for 4 consecutive days. While the single exposure resulted in a decrease in differentiation, ELF-PMF applied every day for $1 \mathrm{~h}$ caused a differentiation increase [13].

\subsubsection{Incidence on Organelles}

MF can break into deeper layers of living tissue and into cells where it may act directly on cell organelles. A $6 \mathrm{mT}$ SMF exposure of up to $72 \mathrm{~h}$ induces on differentiated U937 cells a general redistribution and polarization at the cell periphery of the smooth endoplasmic reticulum, mitochondria, and lysosomes, and in some cases, changes their function [16]. In MF-exposed animals, as expected, organelle alterations of organs commonly affected by abiotic stresses, such as the liver, are observed. In fact, long-term exposure of rats ( $1 \mathrm{~h}$ per day, 3 days weekly for 4 weeks) to either static or time varying MFs of $2 \mathrm{mT}$ causes structural modifications in hepatocyte nuclei as the most prominent ultrastructural change. This is manifested as irregularity of nuclear membranes, widening of the nuclear pores, and heterogeneous distribution of the chromatin material. Swelling, clumping, and deformation of mitochondria, rough endoplasmic reticulum with marked dilation, and distorted lysosomes were also concomitantly observed [5]. 


\subsubsection{Incidence on Genome and Cell Growth and/or Viability}

MF exposure promotes proliferation, cell death, or does not affect overall cell viability, in amplitude-, frequency- and exposure time-dependent ways. Depending on the exposure parameters, an influence on the DNA could be observed. A 4 h exposure to ELF-PMFs ( 0.8 or $1.4 \mathrm{mT})$ produces a reduction by around $15 \%$ of cell viability in differentiated SH-SY5Y cells, concomitantly affecting DNA. This influence can be observed from IR bands due to vibrations of various structural groups in DNA, such as the two phosphate absorption bands around $1235 \mathrm{~cm}^{-1}$ and $1080 \mathrm{~cm}^{-1}$, corresponding to the asymmetric stretching phosphate mode ${ }^{a s} \mathrm{PO}_{2}{ }^{-}$and symmetric stretching phosphate mode of phosphodiester bonds ${ }^{\mathrm{S}} \mathrm{PO}_{2}{ }^{-}$in nucleic acids, respectively [33]. The integrated area of as $\mathrm{PO}_{2}{ }^{-}$ and ${ }^{\mathrm{s}} \mathrm{PO}_{2}{ }^{-}$of exposed cells in comparison to controls, computed from 1260 to $1200 \mathrm{~cm}^{-1}$ and from 1120 to $1020 \mathrm{~cm}^{-1}$, respectively, decreases significantly after the exposure to ELF-PMF at $0.8 \mathrm{mT}$. In addition, the peak's centroid of as $\mathrm{PO}_{2}{ }^{-}$and ${ }^{\mathrm{S}} \mathrm{PO}_{2}{ }^{-}$bands is shifted $9 \mathrm{~cm}^{-1}$ and $3 \mathrm{~cm}^{-1}$, respectively. As an endpoint, a significant reduction of the DNA content is observed following exposure [17]. No significant differences were found about cell viability between sham exposed and $2 \mathrm{mT}, 50 \mathrm{~Hz}$, ELF-PMF exposed Raji cells up to $72 \mathrm{~h}$ [19], whereas HaCaT cells exposed to the same MF, but for a longer time (up to 15 days), showed an increase in both clonogenic capacity and cell growth than controls [31]. A different window of vulnerability is observed on cancer cells with respect to normal ones. An hour of daily exposures to 2, 3 or $5 \mathrm{mT}, 20 \mathrm{~Hz}$, ELF-PMFs for 3 consecutive days gave greater ratios of cell death and greater amounts of DNA fragmentation than 90 min of daily exposure only on breast cancer MCF-7 cells, by not damaging normal MCF-10 cells [34]. A $24 \mathrm{~h}$ exposure to $5 \mathrm{mT}, 10 \mathrm{~Hz}$, ELF-PMF decreases the cell viability and the cyclin-D1 expression levels in glioblastoma U87 cells of $21 \%$ and $34 \%$, respectively. Increases of $30 \%$ and $45 \%$ were instead found when the same cells were exposed, again for $24 \mathrm{~h}$, to a $10 \mathrm{mT}, 50 \mathrm{~Hz}$, ELF-PMF. The protein p53 was downregulated in both exposure conditions, with lower levels of expression as the $B$ and $f$ values increase [7]. Cyclin-D1 is involved in regulating the cell cycle progression, and drives the G1/S phase transition [35], whereas the "guardian of the genome", p53, is an enzyme that plays a central role during the execution of apoptosis [36]. Cell growth arrest at the G1/S checkpoint can be induced by p53, upon DNA damage recognition [37]. Thus, $5 \mathrm{mT}, 10 \mathrm{~Hz}$, ELF-PMF promotes apoptosis by arresting cell division. Conversely, $10 \mathrm{mT}, 50 \mathrm{~Hz}$, ELF-PMF increases the number of cells by shortening the duration of the cell cycle [7]. In normal unstressed cells, p53 has a nuclear localization. Its interaction with the ubiquitin ligase Mouse Double Minute 2 (MDM2) maintains it at low, often undetectable, cellular levels [38]. Interestingly, an abundant presence of p53 is observed in the cytoplasm of PBLs exposed to $6 \mathrm{mT} \mathrm{SMF}$ for up $24 \mathrm{~h}$, hence suggesting that its degradation could be impaired or delayed as a consequence of the exposure [27]. The p53, when present at high levels in the cytoplasm, has an inhibitory effect on caspase-9 [39], which results in apoptosis evasion [2,7,11,12,16,27,34]. A 6 mT SMF does not exert toxic or apoptotic effects, and only slightly interfered with the normal rate of cell viability, depending on both exposure time and cell type $[11,12,16,27,40]$.

\subsubsection{Incidence on Intercellular Communications}

Modification of gap junction number is implicated in cell transformation [41]. Hu et al., (2001) found that a $50 \mathrm{~Hz}$ ELF-PMF, with an intensity of $0.8 \mathrm{mT}$, inhibits the gap junctional intercellular communication (GJIC) and induces hyperphosphorylation of connexin 43 in NIH3T3 fibroblasts exposed for up to $24 \mathrm{~h}$, either alone or in combination with an inhibitor of GJIC, i.e., TPA [42]. Conversely, no direct inhibition of GJIC, nor synergism with TPA-induced inhibition, was observed when the same cells were $24 \mathrm{~h}$ exposed to a $50 \mathrm{~Hz}$ ELF-PMF with a slightly higher $B$ value, i.e., $1 \mathrm{mT}[43]$.

The bystander effect refers to the biological responses (chromosomal aberrations, cell lethality, mutation, and oncogenic transformation) observed in non-irradiated cells when neighbouring cells are exposed. It is believed that the basis of this effect is the spatial communication (mediated by signal molecules, whose nature is still to be determined) between irradiated cells and not, through 
gap junction and/or the culture medium. This effect has been demonstrated for both high- and low-linear energy transfer radiations, but it is usually larger for densely ionizing radiation such as $\alpha$ particles [44]. Interestingly, $10 \mathrm{~min}$ exposure to static and time-varying MFs generated by a standard 1.5 T MRI device, as typically set to perform a routine head scan protocol, induce a bystander response in human adherent epithelial cells derived originally from a foreskin primary culture and immortalized by the HPV virus (HPV-G cells) [45]. As shown in Figure 2, human myeloid leukaemia U937 cells undergo blebbing of their plasma membrane when cultivated for up to $6 \mathrm{~h}$ in conditioned medium harvested from PBLs that previously had been left under exposure for $24 \mathrm{~h}$ to a SMF of $6 \mathrm{mT}$. This plasma membrane blebbing could be due to the apoptotic process onset. In fact, this process takes place according to well-defined stages that are morphologically recognizable: (i) initially, the cell cytoskeleton breaks up and causes the membrane to bulge outward; (ii) during later stages, these bulges separate from the cell as apoptotic bodies, by carrying with them a portion of cytoplasm, larger organelle fragments, such as larger parts of the fragmented apoptotic cell nucleus [46-48]. It has been recently shown that blebs produced by actin-myosin contraction during apoptosis release damage-associated molecular pattern proteins before secondary necrosis onset [47]. Thus, blebs observed in U937 cells cultivated in a conditioned medium and harvested from exposed PBLs could be the recognizable morphological cell change associated with the release of this damage-associated protein that, in turn, triggers the secondary necrosis. Indeed, Teodori et al. had already observed that the same SMF acts as a pro secondary necrosis factor in HL-60 cells [40].

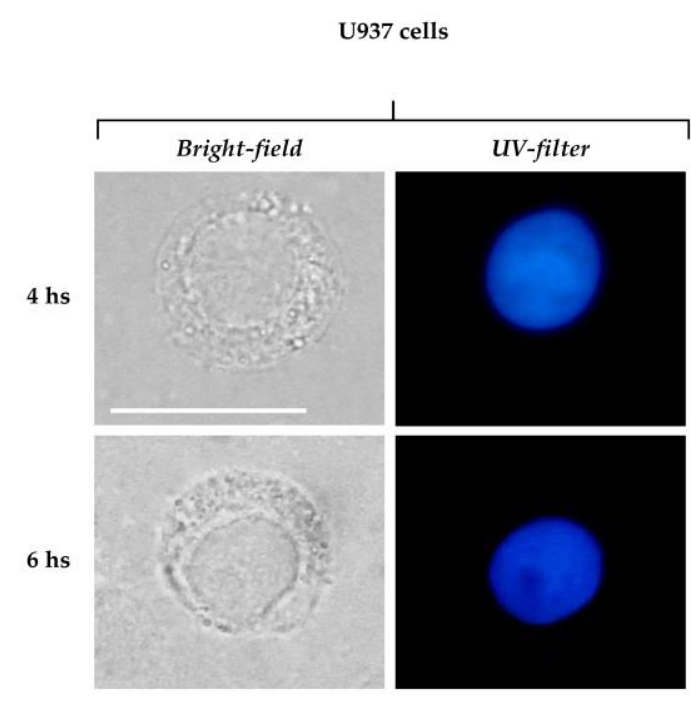

(a)

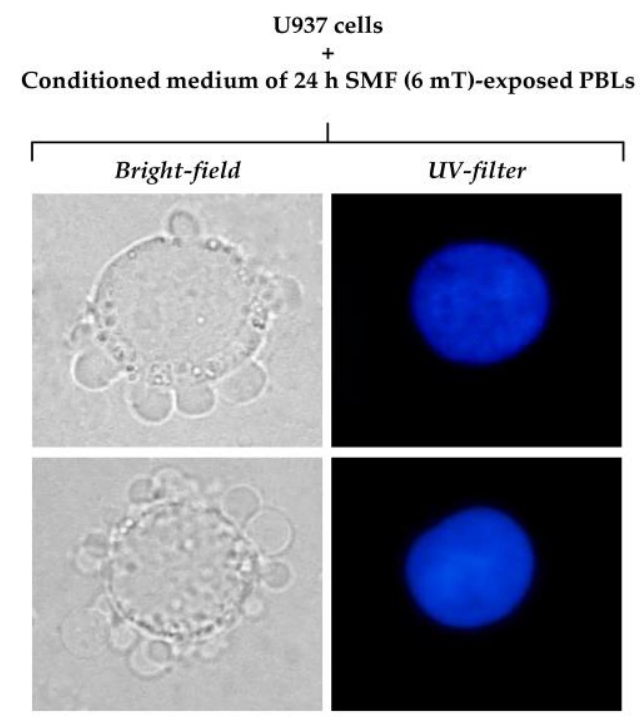

(b)

Figure 2. Hoechst 33342-labeled (fluorescent probe of nucleus) human myeloid leukaemia U937 cells cultivated for up to $6 \mathrm{~h}$ in: (a) RPMI-1640 cell culture medium (with 10\% FBS); (b) conditioned medium (RPMI-1640 with 10\% FBS) harvested from PBLs exposed for $24 \mathrm{~h}$ to $6 \mathrm{mT}$ SMF. Bar $=15 \mu \mathrm{m}$.

\section{Conclusions}

Whether MF exposure is the cause of health risks has led many researchers to examine the mechanisms by which MFs might affect living beings. Static and time-varying MFs with $B$ in the range of 1-60 $\mathrm{mT}$ and $f$ up to $50 \mathrm{~Hz}$ are commonly experienced by the population; therefore, knowledge of their effects on biological systems is essential for the scientific community. As shown in Table 1 , which summarizes the significant outcomes of research over the last 30 years, they affect all cellular components by inducing a multiplicity of biological responses, which very often conflict with each other. Many of these responses are transitory, and normal values can be restored if the MF exposure source is removed. 
Table 1. Common biological effects induced at the cellular level by SMFs vs. ELF-PMFs with $B$ in the range of $1-60 \mathrm{mT}$ and $f$ up to $50 \mathrm{~Hz}$.

\begin{tabular}{|c|c|c|c|c|}
\hline $\begin{array}{l}\text { Cellular/Intercellular Component } \\
\text { or Process Affected }{ }^{1}\end{array}$ & $\begin{array}{l}\text { Magnitude and Frequency } \\
\text { of MF Involved }\end{array}$ & $\begin{array}{c}\text { Duration of Exposure and } \\
\text { Cell Type }\end{array}$ & $\begin{array}{l}\text { Biological Effect } \\
\text { Observed }\end{array}$ & Reference \\
\hline \multicolumn{5}{|l|}{ Cell Membranes: } \\
\hline $\begin{array}{l}\text { - electrical parameters } \\
\text { - conductivity and permittivity }\end{array}$ & $\begin{array}{c}1-10 \mathrm{mT}, 50 \mathrm{~Hz}, \text { ELF-PMFs } \\
\text { 1,3, } 5 \mathrm{mT} \text { SMFs }\end{array}$ & $\begin{array}{l}\text { Up to } 1 \mathrm{~h} \text {, primary } \\
\text { embryonic chicken } \\
\text { myoblasts }\end{array}$ & Contrasting responses & {$[3,4]$} \\
\hline \multirow{2}{*}{$\begin{array}{l}\text { - inner mitochondrial transmembrane } \\
\text { potential }\end{array}$} & $6 \mathrm{mT} \mathrm{SMF}$ & $\begin{array}{l}\text { Up to } 72 \mathrm{~h} \text {, differentiated } \\
\text { U937 cells }\end{array}$ & \multirow[t]{2}{*}{ Variation } & [16] \\
\hline & $\begin{array}{l}\text { Around } 1 \mathrm{mT}(0.81)-1.4 \mathrm{mT} \text {, } \\
50 \mathrm{~Hz}, \text { ELF-PMF }\end{array}$ & $\begin{array}{l}\text { Up to } 4 \mathrm{~h} \text {, differentiated } \\
\text { SH-SY5Y cells }\end{array}$ & & [17] \\
\hline \multirow[b]{2}{*}{ - $\quad$ fluidity } & $2 \mathrm{mT}, 50 \mathrm{~Hz}$, ELF-PMF & Up to $72 \mathrm{~h}$, Raji cells & \multirow{2}{*}{ Decrease } & [19] \\
\hline & $6 \mathrm{mT}, 50 \mathrm{~Hz}$, ELF-PMFs & $\begin{array}{l}\text { Up to weeks, murine brain } \\
\text { and liver cells }\end{array}$ & & [20] \\
\hline \multirow{2}{*}{ - $\quad$ phospholipids } & $1 \mathrm{mT} \leq \mathrm{B}<1 \mathrm{~T} \mathrm{SMF}$ & $\begin{array}{l}\text { Different duration of } \\
\text { exposure and cell types }\end{array}$ & Displacement & {$[22,23]$} \\
\hline & $\begin{array}{l}\text { Around } 1 \mathrm{mT}(0.81)-1.4 \mathrm{mT}, \\
50 \mathrm{~Hz} \text {, ELF-PMF }\end{array}$ & $\begin{array}{l}\text { Up to } 4 \mathrm{~h} \text {, differentiated } \\
\text { SH-SY5Y cells }\end{array}$ & Structural rearrangement & [17] \\
\hline \multirow{3}{*}{ - $\quad$ proteins } & 41.7-43.6 mT, $50 \mathrm{~Hz}$, ELF-PMF & Up to $1 \mathrm{~min}, \mathrm{HeLa}$ cells & \multirow{2}{*}{$\begin{array}{l}\text { Influences on the N-H } \\
\text { inplane bending and C-N } \\
\text { stretching vibrations of } \\
\text { peptide linkages, changes } \\
\text { the secondary structures of } \\
\alpha \text {-helix and } \beta \text {-pleated sheet }\end{array}$} & [24] \\
\hline & $\begin{array}{l}\text { Around } 1 \mathrm{mT}(0.81)-1.4 \mathrm{mT} \text {, } \\
50 \mathrm{~Hz}, \text { ELF-PMF }\end{array}$ & $\begin{array}{l}\text { Up to } 4 \mathrm{~h} \text {, differentiated } \\
\text { SH-SY5Y cells }\end{array}$ & & [17] \\
\hline & $6 \mathrm{mT} \mathrm{SMF}$ & Up to $24 \mathrm{~h}$, human PBLs & $\begin{array}{c}\text { Putative modulation of } \\
\mathrm{Ca}^{2+} / \mathrm{H}^{+} \mathrm{Na}^{+} / \mathrm{H}^{+} \\
\text {antiporters }\end{array}$ & $\begin{array}{c}\text { See } \\
\text { Section 3.2.2 }\end{array}$ \\
\hline \multicolumn{5}{|l|}{ Cell Processes: } \\
\hline \multirow[t]{2}{*}{ - $\quad$ adhesion } & $2 \mathrm{mT}, 50 \mathrm{~Hz}$, ELF-PMF & Up to $96 \mathrm{~h}, \mathrm{HaCaT}$ cells & $\begin{array}{c}\text { Increase, even if cells show } \\
\text { a modified pattern of } \\
\text { adhesion markers }\end{array}$ & [31] \\
\hline & $6 \mathrm{mT} \mathrm{SMF}$ & $\begin{array}{l}\text { Up to } 72 \mathrm{~h} \text {, differentiated } \\
\text { U937 cells }\end{array}$ & Decrease & {$[16,32]$} \\
\hline \multirow{4}{*}{ - apoptosis } & $6 \mathrm{mT} \mathrm{SMF}$ & $\begin{array}{l}\text { Up to } 72 \text { h, human PBLs, } \\
\text { murine thymocytes, 3DO, } \\
\text { U937 (differentiated or not), } \\
\text { HeLa, HepG2, FRTL-5 cells }\end{array}$ & \multirow{4}{*}{$\begin{array}{l}\text { Onset modulation (more } \\
\text { often than not, the MF acts } \\
\text { as an antiapoptotic factor) }\end{array}$} & {$[2,12,16,27]$} \\
\hline & $\begin{array}{l}2,3 \text { or } 5 \mathrm{mT}, 20 \mathrm{~Hz} \\
\text { ELF-PMFs }\end{array}$ & $\begin{array}{l}60 \text { min per day for } 3 \\
\text { consecutive days, MCF-7 } \\
\text { and MCF-10 cells }\end{array}$ & & [34] \\
\hline & $3 \mathrm{mT}, 20 \mathrm{~Hz}$, ELF-PMF & $\begin{array}{c}30,60 \text { or } 90 \text { min per day for } \\
3 \text { consecutive days, MCF-7 } \\
\text { and MCF-10 cells }\end{array}$ & & \\
\hline & $\begin{array}{l}5 \mathrm{mT}, 10 \mathrm{~Hz} \text {, or } 10 \mathrm{mT}, 50 \mathrm{~Hz}, \\
\text { ELF-PMFs }\end{array}$ & Up to $24 \mathrm{~h}, \mathrm{U} 87$ cells & & [7] \\
\hline \multirow[t]{3}{*}{ - differentiation } & $2 \mathrm{mT}, 50 \mathrm{~Hz}$, ELF-PMF & Up to $96 \mathrm{~h}, \mathrm{HaCaT}$ cells & $\begin{array}{l}\text { Speeding up, even if cells } \\
\text { show a modified pattern of } \\
\text { differentiation markers } \\
\text { and are not driven toward } \\
\text { the terminal } \\
\text { differentiation status }\end{array}$ & [31] \\
\hline & $6 \mathrm{mT} \mathrm{SMF}$ & $\begin{array}{l}\text { Up to } 72 \mathrm{~h} \text {, differentiated } \\
\text { U937 cells }\end{array}$ & Decrease & {$[16,32]$} \\
\hline & $5 \mathrm{mT}, 50 \mathrm{~Hz}$, ELF-PMF & $\begin{array}{l}1 \mathrm{~h} \text { or daily } 1 \mathrm{~h} \text { for four days, } \\
\text { K562 cells }\end{array}$ & $\begin{array}{l}\text { Single exposure results in } \\
\text { a decrease, whereas } \\
\text { everyday exposure in } \\
\text { an increase }\end{array}$ & [13] \\
\hline
\end{tabular}


Table 1. Cont.

\begin{tabular}{|c|c|c|c|c|}
\hline $\begin{array}{c}\text { Cellular/Intercellular Component } \\
\text { or Process Affected }{ }^{1}\end{array}$ & $\begin{array}{l}\text { Magnitude and Frequency } \\
\text { of MF Involved }\end{array}$ & $\begin{array}{c}\text { Duration of Exposure and } \\
\text { Cell Type }\end{array}$ & $\begin{array}{l}\text { Biological Effect } \\
\text { Observed }\end{array}$ & Reference \\
\hline \multicolumn{5}{|l|}{ Cell Processes: } \\
\hline \multirow{6}{*}{ - $\quad$ growth and/or viability } & \multirow{2}{*}{$2 \mathrm{mT}, 50 \mathrm{~Hz}$, ELF-PMF } & Up to $72 \mathrm{~h}$, Raji cells & No significant differences & [19] \\
\hline & & Up to 15 days, HaCaT cells & Cell growth increase & [31] \\
\hline & $6 \mathrm{mT} \mathrm{SMF}$ & $\begin{array}{l}\text { Up to } 72 \mathrm{~h} \text {, human PBLs, } \\
\text { murine thymocytes, 3DO, } \\
\text { U937 (differentiated or not), } \\
\text { HeLa, HepG2, FRTL-5, } \\
\text { HL-60 cells }\end{array}$ & $\begin{array}{l}\text { No influence or slight } \\
\text { interference with the } \\
\text { normal rate of cell viability }\end{array}$ & $\begin{array}{c}{[11,12,16,27,} \\
40]\end{array}$ \\
\hline & $\begin{array}{l}\text { Around } 1 \mathrm{mT}(0.81)-1.4 \mathrm{mT}, \\
50 \mathrm{~Hz}, \text { ELF-PMF }\end{array}$ & $\begin{array}{l}\text { Up to } 4 \mathrm{~h} \text {, differentiated } \\
\text { SH-SY5Y cells }\end{array}$ & Cell viability reduction & [17] \\
\hline & $\begin{array}{c}2,3 \text { or } 5 \mathrm{mT}, 20 \mathrm{~Hz} \\
\text { ELF-PMFs }\end{array}$ & $\begin{array}{l}60 \text { min per day for } 3 \\
\text { consecutive days, MCF-7 } \\
\text { and MCF-10 cells }\end{array}$ & $\begin{array}{c}\text { Cell death increase (MCF-7 } \\
\text { cells) or no effect } \\
\text { (MCF-10 cells) }\end{array}$ & [34] \\
\hline & $\begin{array}{c}5 \mathrm{mT}, 10 \mathrm{~Hz} \text {, or } 10 \mathrm{mT}, 50 \mathrm{~Hz}, \\
\text { ELF-PMFs }\end{array}$ & Up to $24 \mathrm{~h}, \mathrm{U} 87$ cells & $\begin{array}{l}\text { Cell viability reduction } \\
(5 \mathrm{mT}, 10 \mathrm{~Hz}) \text { or increase } \\
(10 \mathrm{mT}, 50 \mathrm{~Hz}), \text { by } \\
\text { arresting cell division or } \\
\text { shortening the duration of } \\
\text { the cell cycle, respectively }\end{array}$ & [7] \\
\hline \multirow[t]{2}{*}{ - $\quad$ phagocytosis of dying cells } & $\begin{array}{c}1 \text { or } 1.5 \mathrm{mT}, 50 \mathrm{~Hz}, \\
\text { ELF-PMFs }\end{array}$ & $\begin{array}{l}\text { Up to } 45 \text { min, murine } \\
\text { macrophages }\end{array}$ & $\begin{array}{l}\text { Increased phagocytic } \\
\text { uptake as quantified by } \\
\text { measuring the } \\
\text { internalization rate of } \\
\text { latex beads }\end{array}$ & [49] \\
\hline & $6 \mathrm{mT} \mathrm{SMF}$ & $\begin{array}{l}\text { Up to } 72 \mathrm{~h} \text {, differentiated } \\
\text { U937 cells }\end{array}$ & Delay & {$[16,32]$} \\
\hline \multirow{4}{*}{ - $\quad$ secondary necrosis } & \multirow[b]{2}{*}{$6 \mathrm{mT} \mathrm{SMF}$} & Up to $18 \mathrm{~h}, \mathrm{HL}-60$ cells & \multirow[b]{2}{*}{ Induction } & [40] \\
\hline & & $\begin{array}{l}\text { U937 cells cultivated for up } \\
\text { to } 6 \mathrm{~h} \text { in RPMI- } 1640 \\
\text { conditioned medium from } \\
\text { PBLs exposed for } 24 \mathrm{~h}\end{array}$ & & $\begin{array}{c}\text { See } \\
\text { Section 3.2.6 }\end{array}$ \\
\hline & $\begin{array}{c}2,3 \text { or } 5 \mathrm{mT}, 20 \mathrm{~Hz} \\
\text { ELF-PMFs }\end{array}$ & $\begin{array}{c}60 \text { min per day for } 3 \\
\text { consecutive days, MCF-7 } \\
\text { and MCF-10 cells }\end{array}$ & \multirow{2}{*}{$\begin{array}{l}\text { Increase (MCF-7 cells) or } \\
\text { decrease (MCF-10 cells) }\end{array}$} & \multirow[t]{2}{*}[34]{} \\
\hline & $3 \mathrm{mT}, 20 \mathrm{~Hz}$, ELF-PMF & $\begin{array}{l}30,60 \text { or } 90 \text { min per day for } \\
3 \text { consecutive days, MCF-7 } \\
\text { and MCF-10 cells }\end{array}$ & & \\
\hline \multirow{3}{*}{ Cell Shape } & $2 \mathrm{mT}, 50 \mathrm{~Hz}$, ELF-PMF & $\begin{array}{l}\text { Up to } 72 \mathrm{~h}, \text { Raji cells } \\
\text { Up to } 96 \mathrm{~h}, \mathrm{HaCaT} \text { cells }\end{array}$ & \multirow{3}{*}{ Alteration } & {$[19,31]$} \\
\hline & $\begin{array}{c}2 \mathrm{mT}, 50 \mathrm{~Hz} \text {, ELF-PMF or } \\
6 \mathrm{mT} \text { SMF }\end{array}$ & $\begin{array}{l}\text { Up to } 72 \mathrm{~h} \text {, human PBLs, } \\
\text { murine thymocytes, 3DO, } \\
\text { U937 (differentiated or not), } \\
\text { HeLa, HepG2, FRTL-5 cells }\end{array}$ & & $\begin{array}{c}{[11,12,16,27,} \\
32]\end{array}$ \\
\hline & $5 \mathrm{mT}, 10 \mathrm{~Hz}$, ELF-PMF & Up to $24 \mathrm{~h}, \mathrm{U} 87$ cells & & [7] \\
\hline \multirow[t]{2}{*}{ Cytoskeleton } & $2 \mathrm{mT}, 50 \mathrm{~Hz}$, ELF-PMF & $\begin{array}{l}\text { Up to } 72 \mathrm{~h} \text {, Raji cells } \\
\text { Up to } 96 \mathrm{~h}, \mathrm{HaCaT} \text { cells }\end{array}$ & \multirow{2}{*}{$\begin{array}{l}\text { De-arrangement, } \\
\text { depolymerisation and } \\
\text { marginalization from the } \\
\text { centre towards the cell } \\
\text { membrane of the F-actin } \\
\text { microfilaments }\end{array}$} & {$[19,31]$} \\
\hline & $6 \mathrm{mT} \mathrm{SMF}$ & $\begin{array}{l}\text { Up to } 72 \mathrm{~h} \text {, U937 cells } \\
\text { (differentiated or not) or Raji }\end{array}$ & & {$[16,32]$} \\
\hline \multirow[b]{2}{*}{ Genome } & $\begin{array}{l}\text { Around } 1 \mathrm{mT}(0.81)-1.4 \mathrm{mT}, \\
50 \mathrm{~Hz} \text {, ELF-PMF }\end{array}$ & $\begin{array}{l}\text { Up to } 4 \mathrm{~h} \text {, differentiated } \\
\text { SH-SY5Y cells }\end{array}$ & $\begin{array}{l}\text { Reduction of the } \\
\text { DNA content }\end{array}$ & [17] \\
\hline & $\begin{array}{c}\text { 2, } 3 \text { or } 5 \mathrm{mT}, 20 \mathrm{~Hz} \\
\text { ELF-PMFs }\end{array}$ & $\begin{array}{l}60 \text { min per day for } 3 \\
\text { consecutive days, MCF-7 } \\
\text { and MCF-10 cells }\end{array}$ & $\begin{array}{c}\text { DNA fragmentation } \\
\text { increase (MCF-7 cells) or } \\
\text { no effect (MCF-10 cells) }\end{array}$ & [34] \\
\hline
\end{tabular}


Table 1. Cont.

\begin{tabular}{|c|c|c|c|c|}
\hline $\begin{array}{l}\text { Cellular/Intercellular Component } \\
\text { or Process Affected }^{1}\end{array}$ & $\begin{array}{l}\text { Magnitude and Frequency } \\
\text { of MF Involved }\end{array}$ & $\begin{array}{c}\text { Duration of Exposure and } \\
\text { Cell Type }\end{array}$ & $\begin{array}{l}\text { Biological Effect } \\
\text { Observed }\end{array}$ & Reference \\
\hline \multicolumn{5}{|l|}{ Intercellular Communication: } \\
\hline $\begin{array}{l}\text { - bystander effect through the } \\
\text { culture medium harvested from } \\
\text { exposed cells }\end{array}$ & $6 \mathrm{mT} \mathrm{SMF}$ & $\begin{array}{l}\text { U937 cells cultivated for up } \\
\text { to } 6 \mathrm{~h} \text { in RPMI-1640 } \\
\text { conditioned medium from } \\
\text { human PBLs exposed for } 24 \mathrm{~h}\end{array}$ & $\begin{array}{l}\text { Plasma membrane } \\
\text { blebbing }\end{array}$ & $\begin{array}{c}\text { See } \\
\text { Section 3.2.6 }\end{array}$ \\
\hline \multirow{2}{*}{ - $\quad$ gap junctions } & $\begin{array}{c}\text { Around } 1 \mathrm{mT}(0.8), 50 \mathrm{~Hz}, \\
\text { ELF-PMF }\end{array}$ & \multirow{2}{*}{ Up to $24 \mathrm{~h}, \mathrm{NIH} 3 \mathrm{~T} 3$ cells } & $\begin{array}{l}\text { Inhibition and } \\
\text { hyperphosphorylation of } \\
\text { connexin } 43\end{array}$ & [42] \\
\hline & $1 \mathrm{mT}, 50 \mathrm{~Hz}$, ELF-PMFs & & $\begin{array}{l}\text { No inhibition, nor } \\
\text { synergism with } \\
\text { TPA-induced inhibition }\end{array}$ & [43] \\
\hline \multirow{3}{*}{$\begin{array}{l}\text { Intracellular Calcium } \\
\text { Concentration }\end{array}$} & $22 \mathrm{mT}, 50 \mathrm{~Hz}, \mathrm{ELF}-\mathrm{PMF}$ & $\begin{array}{l}\text { Up to } 1 \mathrm{~h} \text {, murine thymic } \\
\text { lymphocytes }\end{array}$ & $\begin{array}{l}\text { Release from intracellular } \\
\text { stores (early phase) and } \\
\text { influx of extracellular } \\
\text { calcium across the ion } \\
\text { channels (plateau phase) }\end{array}$ & [25] \\
\hline & $6 \mathrm{mT} \mathrm{SMF}$ & $\begin{array}{l}\text { Up to } 48 \text { h, human PBLs, } \\
\text { murine thymocytes, 3DO, } \\
\text { U937 (differentiated or not), } \\
\text { HeLa, HepG2, FRTL-5 cells }\end{array}$ & $\begin{array}{l}\text { Cell type-dependent } \\
\text { upregulation }\end{array}$ & {$[11,12,16,27]$} \\
\hline & $\begin{array}{l}\text { Around } 1 \mathrm{mT}(0.8), 50 \mathrm{~Hz}, \\
\text { ELF-PMF }\end{array}$ & $\begin{array}{c}\text { Up to } 8 \text { min, murine } \\
\text { osteoblasts }\end{array}$ & Uptake & [26] \\
\hline \multicolumn{5}{|l|}{ Organelles: } \\
\hline $\begin{array}{l}\text { - Smooth endoplasmic reticulum, } \\
\text { mitochondria and lysosomes }\end{array}$ & $6 \mathrm{mT} \mathrm{SMF}$ & $\begin{array}{l}\text { Up to } 72 \mathrm{~h} \text {, differentiated } \\
\text { U937 cells }\end{array}$ & $\begin{array}{l}\text { Polarization at the cell } \\
\text { periphery and in some } \\
\text { cases changes their } \\
\text { function }\end{array}$ & [16] \\
\hline $\begin{array}{l}\text { Nuclei, mitochondria, rough } \\
\text { endoplasmic reticulum } \\
\text { and lysosomes }\end{array}$ & $\begin{array}{c}2 \mathrm{mT}, 50 \mathrm{~Hz}, \text { ELF-PMF or } 2 \\
\text { mT SMF }\end{array}$ & $\begin{array}{c}1 \text { h per day, } 3 \text { days weekly } \\
\text { for } 4 \text { weeks, albino rats } \\
\text { (Rattus } \\
\text { norvegicus) }\end{array}$ & $\begin{array}{l}\text { Structural modifications in } \\
\text { hepatocyte nuclei } \\
\text { including irregularity of } \\
\text { nuclear membranes, } \\
\text { widening of the nuclear } \\
\text { pores and heterogeneous } \\
\text { distribution of the } \\
\text { chromatin material. } \\
\text { Swelling, clumping and } \\
\text { deformation of } \\
\text { mitochondria, rough } \\
\text { endoplasmic reticulum } \\
\text { with marked dilation and } \\
\text { distorted lysosomes }\end{array}$ & [5] \\
\hline
\end{tabular}

Note: Listed in alphabetical order.

Many findings highlight 'window' effects, thus making it difficult to define standardized endpoints. Thus, in order to better outline the molecular mechanisms underlying the exposure of living beings to MFs, the following aspects should be considered:

(i) different effects would already be observed with MF exposures of a low magnitude;

(ii) the simultaneous presence of SMF and PMF is the optimal condition in which to study the interaction of MFs with biological systems. In addition, due to the different sources used near to the body, it is important to take into account multiple exposures for risk assessment, which may also require organ-specific dosimetry [8];

(iii) most biological responses are detected using only certain MFs 'windows'.

Research that has been carried out to date lack systematic approaches, and was often performed without appropriately detailing the exposure facilities and exposure assessment procedures used [9]. Many studies have been conducted in vitro, while very few of them have been performed in vivo or at an epidemiological level. Therefore, it is not known if the data obtained in vitro on a specific cell line will be valid for the whole organism. In addition, an unsolvable problem in epidemiological studies is that the people involved in the studies are often exposed to other potentially harmful agents which are sometimes difficult to identify. In addition, the sample size is typically very small $[50,51]$. 
In conclusion, according to evidence-based findings, no definitive health risk assessment due to MF exposure is available for the population.

Author Contributions: All authors contributed equally to this paper.

Funding: This research received no external funding.

Conflicts of Interest: The authors declare no conflict of interest.

\section{References}

1. Vernadsky, V.I.; McMenamin, M.A. The Biosphere; Langmuir, D.B., McMenamin, M.A.S., Eds.; Copernicus Publisher: Göttingen, Germany, 1997; pp. 1-192, ISBN 10 038798268X, ISBN 139780387982687.

2. Vergallo, C.; Piccoli, C.; Romano, A.; Panzarini, E.; Serra, A.; Manno, D.; Dini, L. Magnetostatic Field System for Uniform Cell Cultures Exposure. PLoS ONE 2013, 8, e72341. [CrossRef] [PubMed]

3. Grandolfo, M.; Santini, M.T.; Vecchia, P.; Bonincontro, A.; Cametti, C.; Indovina, P.L. Non-linear dependence of the dielectric properties of chick embryo myoblast membranes exposed to a sinusoidal $50 \mathrm{~Hz}$ magnetic field. Int. J. Radiat. Biol. 1991, 60, 877-890. [CrossRef] [PubMed]

4. Santini, M.T.; Cametti, C.; Straface, E.; Grandolfo, M.; Indovina, P.L. A static magnetic field does not affect the dielectric properties of chick embryo myoblast membranes. Int. J. Radiat. Biol. 1994, 65, 277-284. [CrossRef] [PubMed]

5. El-Hady El-desoky, M.; Mohamady, M. Ultrastructural studies on the effect of electromagnetic field on the liver of albino rats (Rattus Norvegicus). J. Am. Sci. 2011, 7, 154-165. Available online: http:/ /www. jofamericanscience.org/journals/am-sci/am0702/22_4534am0702_154_165_mohamed.pdf (accessed on 11 May 2018).

6. Tenuzzo, B.A.; Vergallo, C.; Dini, L. Early Development of Sea Urchin P.lividus under Static (6 mT) and Pulsed Magnetic Fields (15 and $72 \mathrm{~Hz}$ ). Curr. Chem. Boil. 2016, 10, 32-42. [CrossRef]

7. Akbarnejad, Z.; Eskandary, H.; Vergallo, C.; Nematollahi-Mahani, S.N.; Dini, L.; Darvishzadeh-Mahani, F.; Ahmadi, M. Effects of extremely low-frequency pulsed electromagnetic fields (ELF-PEMFs) on glioblastoma cells (U87). Electromagn. Biol. Med. 2017, 36, 238-247. [CrossRef] [PubMed]

8. Scientific Committee on Emerging and Newly Identified Health Risks. Opinion on Potential Health Effects of Exposure to Electromagnetic Fields (EMF); European Commission: Luxembourg, 2015; pp. 1-288. [CrossRef]

9. World Health Organization. Static Fields-Environmental Health Criteria, No. 232; World Health Organization Press: Geneva, Switzerland, 2006; pp. 1-368, ISBN 92-4-157232-9.

10. Scientific Committee on Emerging and Newly Identified Health Risks. Health Effects of Exposure to EMF; European Commission: Brussels, Belgium, 2009; pp. 1-83. Available online: http:/ / ec.europa.eu/health/ ph_risk/committees/04_scenihr/docs/scenihr_O_022.pdf (accessed on 13 February 2018).

11. Chionna, A.; Dwikat, M.; Panzarini, E.; Tenuzzo, B.; Carlà, E.C.; Verri, T.; Pagliara, P.; Abbro, L.; Dini, L. Cell shape and plasma membrane alterations after static magnetic fields exposure. Eur. J. Histochem. 2003, 47, 299-308. Available online: https://staff-old.najah.edu/sites/default/files/Cell_Shape_and_Plasma_ Membrane_Alterations_after_Static_Magnetic_Fields_Exposure.pdf (accessed on 7 May 2018). [CrossRef] [PubMed]

12. Tenuzzo, B.; Chionna, A.; Panzarini, E.; Lanubile, R.; Tarantino, P.; Di Jeso, B.; Dwikat, M.; Dini, L. Biological effects of $6 \mathrm{mT}$ static magnetic fields: A comparative study in different cell types. Bioelectromagnetics 2006, 27, 560-577. [CrossRef] [PubMed]

13. Ayşe, I.G.; Zafer, A.; Sule, O.; Işil, I.T.; Kalkan, T. Differentiation of K562 cells under ELF-EMF applied at different time courses. Electromagn. Biol. Med. 2010, 29, 122-130. [CrossRef] [PubMed]

14. Sutton, R.; Kanal, E.; Wilkoff, B.L.; Bello, D.; Luechinger, R.; Jenniskens, I.; Hull, M.; Sommer, T. Safety of magnetic resonance imaging of patients with a new Medtronic EnRhythm MRI SureScan pacing system: Clinical study design. Trials 2008, 9, 68. [CrossRef] [PubMed]

15. Vistnes, A.I. Electromagnetic fields at home. In Radiation at Home, Outdoors and in the Workplace; Brune, D., Hellborg, R., Persson, B.R.R., Pääkkönen, R., Eds.; Scandinavian Science: Oslo, Norway, 2001; pp. 286-305, ISBN 82-91833-02-8. 
16. Dini, L.; Dwikat, M.; Panzarini, E.; Vergallo, C.; Tenuzzo, B. Morphofunctional study of 12-O-tetradecanoyl-13-phorbol acetate (TPA)-induced differentiation of U937 cells under exposure to a $6 \mathrm{mT}$ static magnetic field. Bioelectromagnetics 2009, 30, 352-364. [CrossRef] [PubMed]

17. Calabrò, E.; Condello, S.; Currò, M.; Ferlazzo, N.; Vecchio, M.; Caccamo, D.; Magazù, S.; Ientile, R. 50 Hz electromagnetic field produced changes in FTIR spectroscopy associated with mitochondrial transmembrane potential reduction in neuronal-like SH-SY5Y cells. Oxid. Med. Cell. Longev. 2013, 2013, 414393. [CrossRef]

18. Ye, H.; Cotic, M.; Kang, E.E.; Fehlings, M.G.; Carlen, P.L. Transmembrane potential induced on the internal organelle by a time-varying magnetic field: A model study. J. Neuroeng. Rehabil. 2010, 7, 12. [CrossRef] [PubMed]

19. Santoro, N.; Lisi, A.; Pozzi, D.; Pasquali, E.; Serafino, A.; Grimaldi, S. Effect of extremely low frequency (ELF) magnetic field exposure on morphological and biophysical properties of human lymphoid cell line (Raji). Biochim. Biophys. Acta 1997, 1357, 281-290. [CrossRef]

20. Liu, Y.; Weng, E.; Zhang, Y.; Hong, R. Effects of extremely low frequency electromagnetic field and its combination with lead on the antioxidant system in mouse. Zhonghua Lao Dong Wei Sheng Zhi Ye Bing Za Zhi 2002, 20, 263-265. Available online: https:/ / www.ncbi.nlm.nih.gov/pubmed/14694649 (accessed on 9 May 2018).

21. Worcester, D.L. Structural origins of diamagnetic anisotropy in proteins. Proc. Natl. Acad. Sci. USA 1978, 75, 5475-5477. Available online: https:/ / www.ncbi.nlm.nih.gov/pmc/articles/PMC392987/pdf/pnas000210237.pdf (accessed on 16 April 2018). [CrossRef] [PubMed]

22. Dini, L.; Vergallo, C. Environmental Factors Affecting Phagocytosis of Dying Cells: Smoking and Static Magnetic Fields. In Phagocytosis of Dying Cells: From Molecular Mechanisms to Human Diseases; Krysko, D.V., Vandenabeele, P., Eds.; Springer: Dordrecht, The Netherlands, 2009; pp. 409-438. [CrossRef]

23. Rosen, A. Studies on the Effect of Static Magnetic Fields on Biological Systems. PIERS Online 2010, 6, $133-136$. [CrossRef]

24. Ikehara, T.; Yamaguchi, H.; Hosokawa, K.; Miyamoto, H.; Aizawa, K. Effects of ELF magnetic field on membrane protein structure of living HeLa cells studied by Fourier transform infrared spectroscopy. Bioelectromagnetics 2003, 24, 457-464. [CrossRef] [PubMed]

25. Liburdy, R.P. Calcium signaling in lymphocytes and ELF fields. Evidence for an electric field metric and a site of interaction involving the calcium ion channel. FEBS Lett. 1992, 301, 53-59. [CrossRef]

26. Zhang, X.; Liu, X.; Pan, L.; Lee, I. Magnetic fields at extremely low-frequency $(50 \mathrm{~Hz}, 0.8 \mathrm{mT})$ can induce the uptake of intracellular calcium levels in osteoblasts. Biochem. Biophys. Res. Commun. 2010, 396, 662-666. [CrossRef] [PubMed]

27. Tenuzzo, B.; Vergallo, C.; Dini, L. Effect of $6 \mathrm{mT}$ static magnetic field on the bcl-2, bax, p53 and hsp70 expression in freshly isolated and in vitro aged human lymphocytes. Tissue Cell 2009, 41, 169-179. [CrossRef] [PubMed]

28. Li, F.; Song, J.; Qi, H.; Sui, F.; Li, G.; Wang, Q. Effects of static magnetic fields on the physical and chemical properties of cell culture medium RPM1 1640. Electromagn. Biol. Med. 2007, 26, 25-32. [CrossRef] [PubMed]

29. Bevza, A.V.; Kucherenko, S.M. $\mathrm{Ca}^{2+} / \mathrm{H}^{+}$exchange in the lymphocyte plasma membrane. Ukrainskii Biokhimicheskii Zhurnal 1978, 70, 53-58. Available online: https://www.ncbi.nlm.nih.gov/ pubmed/9848140 (accessed on 4 May 2018).

30. Saleh, A.M.; Batlle, D.C. Kinetic properties of the $\mathrm{Na}^{+} / \mathrm{H}^{+}$antiporter of lymphocytes from the spontaneously hypertensive rat: Role of intracellular pH. J. Clin. Investig. 1990, 85, 1734-1739. [CrossRef] [PubMed]

31. Manni, V.; Lisi, A.; Pozzi, D.; Rieti, S.; Serafino, A.; Giuliani, L.; Grimaldi, S. Effects of extremely low frequency $(50 \mathrm{~Hz})$ magnetic field on morphological and biochemical properties of human keratinocytes. Bioelectromagnetics 2002, 23, 298-305. [CrossRef] [PubMed]

32. Pagliara, P.; Lanubile, R.; Dwikat, M.; Abbro, L.; Dini, L. Differentiation of monocytic U937 cells under static magnetic field. Eur. J. Histochem. 2005, 49, 75-86. Available online: http: / citeseerx.ist.psu.edu/viewdoc/ download?doi=10.1.1.883.4659\&rep=rep1\&type=pdf (accessed on 7 May 2018). [CrossRef] [PubMed]

33. Parker, F.S. Applications of Infrared Spectroscopy in Biochemistry, Biology, and Medicine; Plenum Press: New York, NY, USA, 1971; pp. 271-314, ISBN 978-1-4684-1872-9.

34. Crocetti, S.; Beyer, C.; Schade, G.; Egli, M.; Fröhlich, J.; Franco-Obregón, A. Low intensity and frequency pulsed electromagnetic fields selectively impair breast cancer cell viability. PLoS ONE 2013, 8, e72944. [CrossRef] [PubMed] 
35. Imoto, M.; Tanabe, K.; Simizu, S.; Tashiro, E.; Takada, M.; Umezawa, K. Inhibition of cyclin D1 expression and induction of apoptosis by inostamycin in small cell lung carcinoma cells. Jpn. J. Cancer Res. 1998, 89, 315-322. [CrossRef] [PubMed]

36. Hadjiloucas, I.; Gilmore, A.P.; Bundred, N.J.; Streuli, C.H. Assessment of apoptosis in human breast tissue using an antibody against the active form of caspase 3: Relation to tumour histopathological characteristics. Br. J. Cancer 2001, 85, 1522-1526. [CrossRef] [PubMed]

37. Aylon, Y.; Oren, M. Living with p53, dying of p53. Cell 2007, 130, 597-600. [CrossRef] [PubMed]

38. Sutcliffe, J.E.; Brehm, A. Of flies and men; p53, a tumour suppressor. FEBS Lett. 2004, 567, 86-91. [CrossRef] [PubMed]

39. Chee, J.L.; Saidin, S.; Lane, D.P.; Leong, S.M.; Noll, J.E.; Neilsen, P.M.; Phua, Y.T.; Gabra, H.; Lim, T.M. Wild-type and mutant p53 mediate cisplatin resistance through interaction and inhibition of active caspase-9. Cell Cycle 2013, 12, 278-288. [CrossRef] [PubMed]

40. Teodori, L.; Grabarek, J.; Smolewski, P.; Ghibelli, L.; Bergamaschi, A.; De Nicola, M.; Darzynkiewicz, Z. Exposure of cells to static magnetic field accelerates loss of integrity of plasma membrane during apoptosis. Cytometry 2002, 9, 113-118. [CrossRef] [PubMed]

41. Hsu, M.; Andl, T.; Li, G.; Meinkoth, J.L.; Herlyn, M. Cadherin repertoire determines partner-specific gap junctional communication during melanoma progression. J. Cell. Sci. 2000, 113, 1535-1542. Available online: http:/ /jcs.biologists.org/content/113/9/1535 (accessed on 11 May 2018).

42. Hu, G.L.; Chiang, H.; Zeng, Q.L.; Fu, Y.D. ELF magnetic field inhibits gap junctional intercellular communication and induces hyperphosphorylation of connexin43 in NIH3T3 cells. Bioelectromagnetics 2001, 22, 568-573. [CrossRef] [PubMed]

43. Percherancier, Y.; Goudeau, B.; Charlet de Sauvage, R.; de Gannes, F.P.; Haro, E.; Hurtier, A.; Sojic, N.; Lagroye, I.; Arbault, S.; Veyret, B. Effects of $50 \mathrm{~Hz}$ magnetic fields on gap junctional intercellular communication in NIH3T3 cells. Bioelectromagnetics 2015, 36, 287-293. [CrossRef] [PubMed]

44. Hall, E.J. The bystander effect. Health Phys. 2003, 85, 31-35. Available online: https://insights.ovid.com/ pubmed?pmid=12852468 (accessed on 21 March 2018). [CrossRef] [PubMed]

45. Mothersill, C.; Moran, G.; McNeill, F.; Gow, M.D.; Denbeigh, J.; Prestwich, W.; Seymour, C.B. A role for bioelectric effects in the induction of bystander signals by ionizing radiation? Dose-Response 2007, 5, $214-229$. [CrossRef] [PubMed]

46. Vermeulen, K.; Van Bockstaele, D.R.; Berneman, Z.N. Apoptosis: Mechanisms and relevance in cancer. Ann. Hematol. 2005, 84, 627-639. [CrossRef] [PubMed]

47. Wickman, G.R.; Julian, L.; Mardilovich, K.; Schumacher, S.; Munro, J.; Rath, N.; Zander, S.A.L.; Mleczak, A.; Sumpton, D.; Morrice, N.; et al. Blebs produced by actin-myosin contraction during apoptosis release damage-associated molecular pattern proteins before secondary necrosis occurs. Cell Death Differ. 2013, 20, 1293-1305. [CrossRef] [PubMed]

48. Tixeira, R.; Caruso, S.; Paone, S.; Baxter, A.A.; Atkin-Smith, G.K.; Hulett, M.D.; Poon, I.K. Defining the morphologic features and products of cell disassembly during apoptosis. Apoptosis 2017, 22, 475-477. [CrossRef] [PubMed]

49. Simkó, M.; Droste, S.; Kriehuber, R.; Weiss, D.G. Stimulation of phagocytosis and free radical production in murine macrophages by $50 \mathrm{~Hz}$ electromagnetic fields. Eur. J. Cell Biol. 2001, 80, 562-566. [CrossRef] [PubMed]

50. World Health Organization (WHO); International Agency for Research on Cancer (IARC). Non-Ionizing Radiation, Part 1: Static and Extremely Low-Frequency (ELF) Electric and Magnetic Fields. IARC Working Group on the Evaluation of Carcinogenic Risks to Humans; International Agency for Research on Cancer: Lyon, France, 2002; Volume 80, pp. 1-395, ISBN 92-832-1280.

51. Scientific Committee on Emerging; Newly Identified Health Risks. Research Needs and Methodology to Address the Remaining Knowledge Gaps on the Potential Health Effects of EMF; European Commission: Brussels, Belgium, 2009; pp. 1-28. Available online: http:/ / ec.europa.eu/health/ph_risk/committees/04_scenihr/ docs/scenihr_o_024.pdf (accessed on 23 February 2018).

(C) 2018 by the authors. Licensee MDPI, Basel, Switzerland. This article is an open access article distributed under the terms and conditions of the Creative Commons Attribution (CC BY) license (http:/ / creativecommons.org/licenses/by/4.0/). 